Landslides (2022) 19:533-535

DOI 10.1007/s10346-021-01819-x

Published online: 31 January 2022

(c) The Author(s) 2022

\author{
Shinji Sassa • Stephan T. Grilli • David R. Tappin - Kyoji Sassa • \\ Dwikorita Karnawati · Viacheslav K. Gusiakov · Finn Løvholt \\ Understanding and reducing the disaster risk \\ of landslide-induced tsunamis: a short summary \\ of the panel discussion in the World Tsunami \\ Awareness Day Special Event of the Fifth World \\ Landslide Forum
}

\begin{abstract}
A World Tsunami Awareness Day Special Event was held in hybrid mode on 5 November 2021, during the Fifth World Landslide Forum, in Kyoto, Japan. In this context, a panel discussion was organized across America, Europe, and Asia, with the goal to better understand and reduce the disaster risk of landslide-induced tsunamis, consistent with the Kyoto Landslide Commitment 2020. This article presents a short summary of this panel discussion.
\end{abstract}

Keywords Landslide-induced tsunami · Hazard mapping · Early warning $\cdot$ Multi-phased physics $\cdot$ Multiple mechanisms

Introduction

On November 5, 2021, a World Tsunami Awareness Day Special Event was organized during the Fifth World Landslide Forum (WLF5), in Kyoto, Japan. A Landslide-induced Tsunami session was held on November 4, 2021. The World Tsunami Awareness Day Special Event and the Landslide-induced Tsunami session featured twenty-three relevant papers from thirteen countries/regions. These papers were included in the four types of publications for WLF5: Thematic Issue of Journal Landslides ( 3 ; 2020), Full Color Book (11; Sassa et al. 2020), Electronic Proceedings $(3 ; 2020)$ and One-Page Abstract Volume (6; 2021). The key topics ranged from numerical modeling and analysis of landslide-generated waves in rivers, to tsunami uncertainty due to landslide dynamics, using statistics to understand submarine landslide processes and hazard, tsunamis from submarine landslides triggered on islands, simulations of tsunami waves induced by coastal and submarine landslides, tsunami generation by volcanic flank collapse, underestimated tsunami hazard from submarine landslides, landslide-induced icy tsunamis in a reservoir, tsunami early warning system, and tsunami disaster caused by earthquake-induced submarine landslides.

Following the individual presentations, a panel discussion was held across America, Europe, and Asia, with the goal to better understand and reduce the disaster risk of landslide-induced tsunamis, consistent with the Kyoto Landslide Commitment 2020 (KLC2020). The KLC2020, which was launched with 90 signatory organizations worldwide on 5 November 2020 , is a stable framework/partnership for the Global Promotion of Understanding and Reducing Landslide Disaster Risk: A Commitment to the ISDR-ICL Sendai Partnerships 2015-2025, the Sendai Framework for Disaster Risk Reduction 20152030, the 2030 Agenda Sustainable Development Goals, the New Urban Agenda and the Paris Climate Agreement.
Shinji Sassa (S. S.) served as the coordinator of the World Tsunami Awareness Day Special Event during WLF5 and organized the Panel Discussion. The panelists were Stephan T. Grilli (USA), David R. Tappin (UK), Kyoji Sassa (Japan), Dwikorita Karnawati (Indonesia), Viacheslav K. Gusiakov (Russia), and Finn Løvholt (Norway) (S. G., D. T., K. S., D. K., V. G., F. L., respectively). This article presents the framework, essential content, and a short summary of the Panel Discussion.

\section{Panel discussion}

S. S. first introduced and presented the framework of the Panel Discussion. Each panelist then provided a few slide-talks covering what they considered to be essential for better understanding and reducing the disaster risk of landslide-induced tsunamis. This was followed by a general discussion moderated by the coordinator. At the conclusion, the coordinator presented a short summary of the Panel Discussion which was endorsed by all panelists. The framework, essential content, and a short summary of this Panel Discussion are concisely shown in Fig. 2.

Specifically, for better understanding and reducing the disaster risk of landslide-induced tsunamis, S. G. presented three fundamental and important issues, namely: 1. Triggering: when, where, how? 2. Tsunami generation and propagation: magnitude, where, how? 3 . Landslide tsunami detection: magnitude/where? D. T. presented a global map of submarine landslide tsunami locations (Fig. 1), noting that a broad global understanding of the hazard and mapping is required. K. S. presented simulations of coastal and submarine landslide-induced tsunamis and highlighted the important role of landslide motion in tsunami generation. D. K. presented controlling factors and characteristics of areas typically prone to landslides and provided a mitigation strategy based on hazard maps and evacuation plans. V. G. demonstrated the close relationship between oceanic sedimentation zones and landslide-triggered tsunamigenic potential, which could directly contribute to improving tsunami early warning and long-term risk assessment. Finally, F. L. stressed the lack of data for landslide volume probability, resulting from limited seafloor sub-bottom mapping, and highlighted the uncertainty in landslide dynamics leading to tsunami genesis.

During the general Panel Discussion, each of the key items summarized in Fig. 2 was critically discussed among the panelists (S. G., D. T., K. S., D. K., V. G., F. L.) and the coordinator (S. S.), and 


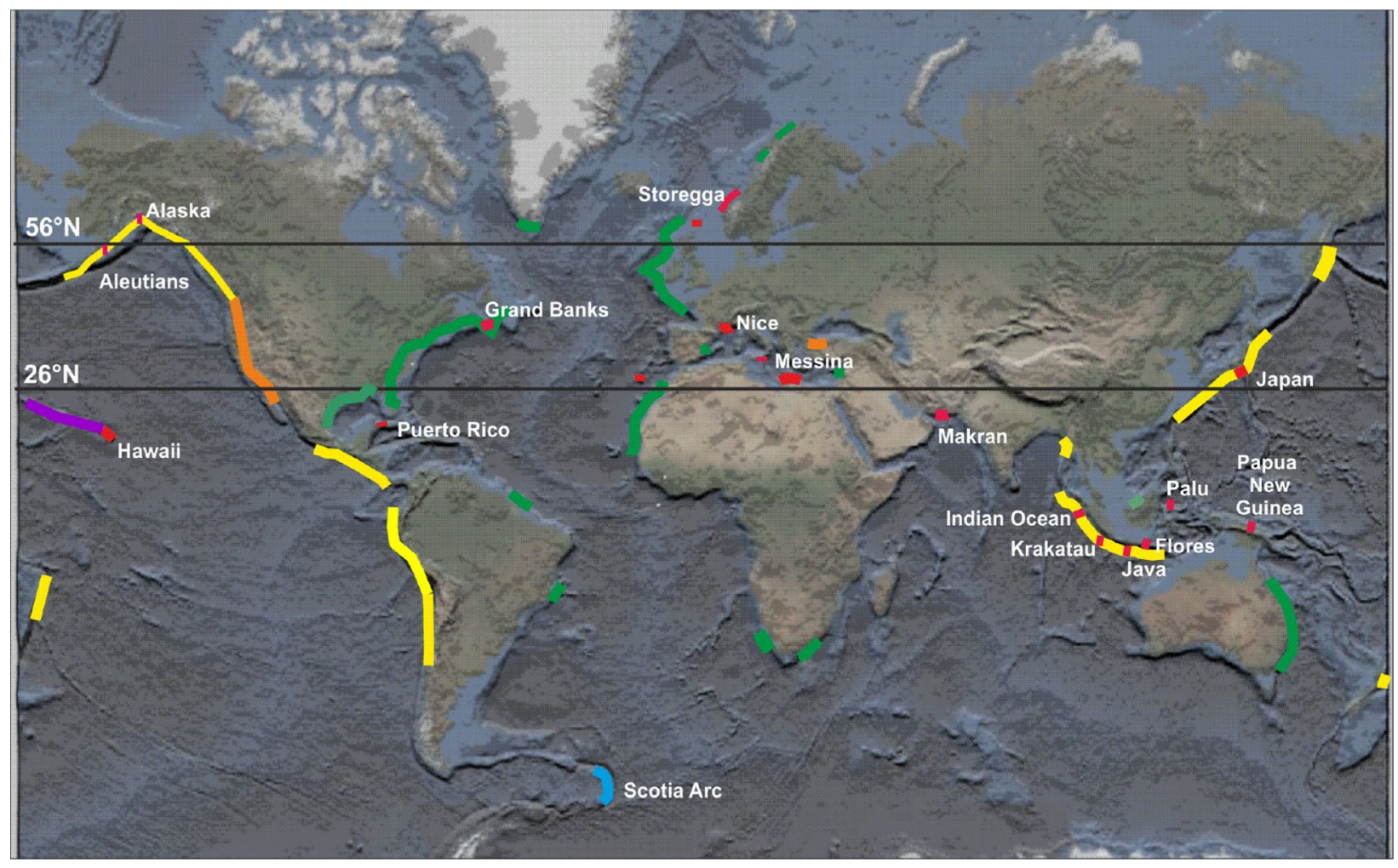

Fig. 1 Global distribution of mapped submarine landslides (SLs): green, SLs on passive margins; yellow, SLs located along convergent margins; orange, SLs on strike slip margins; purple, volcanoes; red, tsunamis associated with SLs (Tappin and Grilli 2020). Submarine landslide tsunamis (in red) are mainly located along convergent margins, but also along passive and strike slip margins and on flanks of volcanoes similarities and connections were recognized between items. Key discussion points are briefly listed in the following. Triggering and source mechanisms need to be well constrained (S. G.), and one needs to better understand how both of these affect tsunami generation, in order to more accurately predict/model landslide-induced tsunamis (S. G., S. S.). There is still a lot to learn (D. T.) for better understanding and mitigating the disaster risk of landslide-induced tsunamis, regarding hazard mapping and improving warning (D. T., S.S.). Dual and multiple mechanisms must be considered to achieve improved mitigation (D. T.). However, our limited understanding and characterization of past events (D. T., F. L.) makes it difficult to well constrain landslide dynamics (F. L.). Landslide dynamics controls tsunami generation (genesis) but is inherently uncertain (F. L.); hence, a better integrated understanding of landslide
Fig. 2 The framework, essential content, and a short summary of the panel discussion in the World Tsunami Awareness Day Special Event of the Fifth World Landslide Forum
Essentials for understanding and reducing the disaster risk of Landslide-induced Tsunamis $\underline{\text { S. Sassa }}$

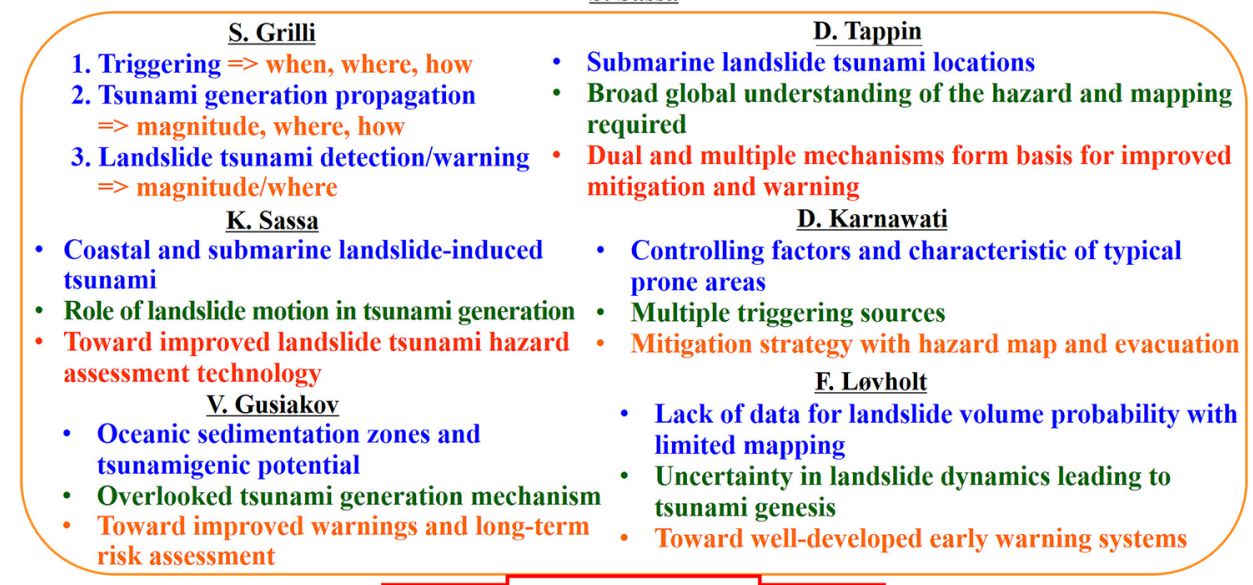

Better understanding of multiple mechanisms and multi-phased physics of Landslide Tsunami Hazard Hazard Mapping / Improved Early Warning 
dynamics as well as multi-phased physics of landslide-water interactions is crucial to reducing landslide tsunami disaster risk (S. S., F. L.). Landslide dynamics itself features complex physics, such as liquefaction and evolutions of pore water pressures involving phase change processes (S. S., K. S.), and the in-depth understanding of such phenomena is important for improving landslide tsunami hazard assessment technologies (K. S., S. S.). A closer investigation of landslides that have caused tsunamis is thus very important (K. S.). In this respect, multiple triggering sources of tsunamis such as landslides caused by earthquakes and volcanic eruptions must be better understood (D. K.). Large volcanic flank collapses have induced large tsunamis, e.g., recently Anak Krakatau 2018 (S. G.); hence, sites of potential future events should be closely monitored and new instruments, allowing for early detection and warning, deployed (S. G., D. K.). In contrast, some landslide-induced tsunamis may impact shores very rapidly, such as in the cases of coastal and submarine landslide-induced tsunamis, e.g., recently Palu 2018 (D. K., S. S., K. S.). Therefore, in order to prepare for such fast arriving tsunamis, hazard mapping is critically important (S.S., D. K.). Accordingly, both hazard maps and 24 -h warning are vital as mitigation strategies (D. K., S. S.). In light of multiple mechanisms, oceanic sedimentation conditions/zones have been overlooked as having high submarine landslide tsunami generation potential ( V. G.); these can play a significant role in improving early warning and hazard maps (V.G., S. S.). Coastal tsunami zoning is also fundamental for the long-term tsunami risk assessment (V.G.).

In closing, many panelists stressed that more data is needed to better constrain geological and geotechnical conditions for hazard mapping (D. T., F. L.). Landslide-water interactions are currently poorly constrained, and their better understanding, together with that of the complex multi-phased physics this entails, is crucial towards developing early warning systems (F. L., S. S., S. G.). Overall, all the panelists and the coordinator agreed that developing a better understanding of the multiple mechanisms and multi-phased physics governing landslide tsunami hazard is important and necessary for improving landslide tsunami hazard mapping and early warning.

\section{Summary}

The Panel Discussion held across America, Europe, and Asia in the World Tsunami Awareness Day Special Event of the Fifth World Landslide Forum has produced an important outcome. All the panelists and the coordinator concur that hazard mapping and improved early warning are essential for better understanding and reducing the disaster risk of landslide-induced tsunamis. Achieving this will require developing a better integrated understanding of the multiple mechanisms and multi-phased physics of landslide tsunami hazard. Thus, it is desirable to develop an international collaborative network/platform, at both the regional and global scales, for the benefit of society and best practice. A more detailed outcome of this panel discussion and the World Tsunami Awareness Special Event will be reported in the new open access book series titled "Progress in Landslide Research and Technology".
Open Access This article is licensed under a Creative Commons Attribution 4.0 International License, which permits use, sharing, adaptation, distribution and reproduction in any medium or format, as long as you give appropriate credit to the original author(s) and the source, provide a link to the Creative Commons licence, and indicate if changes were made. The images or other third party material in this article are included in the article's Creative Commons licence, unless indicated otherwise in a credit line to the material. If material is not included in the article's Creative Commons licence and your intended use is not permitted by statutory regulation or exceeds the permitted use, you will need to obtain permission directly from the copyright holder. To view a copy of this licence, visit http://creativecommons.org/licenses/by/4.o/.

\section{References}

Electronic proceedings of the Fifth World Landslide Forum (2020) pp 280-306

One-page abstract volume of the Fifth World Landslide Forum (2021) pp 28-33, pp 411-423

Sassa K, Mikoš M, Sassa S, Bobrowsky PT, Takara K, Dang K (2020) Understanding and reducing landslide disaster risk: volume 1 Sendai landslide partnerships and Kyoto Landslide Commitment, part III landslide-induced tsunamis. Springer Nature. pp 295-412

Tappin DR, Grilli ST (2020) The continuing underestimated tsunami hazard from submarine landslides. In: Sassa K, Mikoš M, Sassa S, Bobrowsky PT, Takara K, Dang K (eds) Understanding and reducing landslide disaster risk: volume 1 Sendai landslide partnerships and Kyoto Landslide Commitment. pp 343-350

Thematic issue: Sendai landslide partnerships 2015-2025 (2020) Landslides 17(10):2301-2341

\section{Shinji Sassa $(\triangle)$}

Port and Airport Research Institute, National Institute of Maritime, Port and Aviation Technology, Yokosuka, Japan

Email: sassa@p.mpat.go.jp

\section{Stephan T. Grilli}

Department of Ocean Engineering, University of Rhode Island, Narragansett, RI, USA

David R. Tappin

British Geological Survey, Keyworth, Nottingham, UK

\section{Kyoji Sassa}

International Consortium on Landslides, Kyoto, Japan

\section{Dwikorita Karnawati}

Agency for Meteorology, Climatology and Geophysics

of the Republic of Indonesia, Jakarta, Indonesia

Viacheslav K. Gusiakov

Institute of Computational Mathematics and Mathematical Geophysics, Russian Academy of Sciences, Novosibirsk, Russia

Finn Løvholt

Norwegian Geotechnical Institute, Oslo, Norway 